\title{
Preferences of mule deer for 16 grasses found on Intermountain winter ranges
}

\author{
DENNIS D. AUSTIN, RICHARD STEVENS, KENT R. JORGENSEN AND PHILIP J. URNESS
}

\begin{abstract}
Authors 1,4 are research biologist and professor, Range Science Department, Utah State University, Logan, 84322-5230; Authors 2,3 are project leader and research biologist, Great Basin Experiment Station, Ephraim, Utah. 84627.
\end{abstract}

\begin{abstract}
In rangeland revegetation, selection of forages palatable to the primary grazer is crucial. Five tame mule deer were used in the spring and fall to determine forage preferences for 16 grasses commonly found on seeded foothill rangelands. Trials were conducted within a planted enclosure. Cheatgrass (Bromus tectorum L.) was the most preferred species in spring, and also preferred in fall. Other preferred species included 'Paiute' orchardgrass (Dactylis glomerata L.), 'Luna' pubescent wheatgrass (Agropyron trichophorum link.), and fairway wheatgrass (Agropyron cristatum [L.] Gaertn). The least preferred grasses were three species of wildrye, 'Vinall' and 'Boisoisky' Russian wildrye (Psathyrostachys juncea Fisch.) and 'Magnar' basin wildrye (Elymus cinereus Scrib. and Merr.). Results showed a wide range of preferences for grasses.
\end{abstract}

Key Words: mule deer, seeding, grasses, diet, forage preferences, winter range

The grass component in the year-long diet of mule deer is generally small compared to the amount of forbs and browse consumed (Kufeld et al. 1973). Consumption of grasses is primarily limited to early spring, before ample forbs become available, and fall if late summer precipitation stimulates regrowth (Austin and Urness 1983, Willms and McLean 1978). Availability of nutritious new growth in the fall improves body condition, delays utilization of fat and reduces subsequent winter mortality (Urness et al. 1983, Wallmo et al. 1977). The timing of spring green-up is important to ending overwinter mortality and rapid physical recovery, particularly for lactating does (Moen 1978).

The values of improving depleted or burned big game winter ranges through revegetation are evident, and the selection of species used in planting is critical to success in terms of plant establishment and persistence, erosion control, and increased forage availability and quality (Plummer et al. 1968). The objective of this study was to determine preferences of mule deer for various grasses used for revegetation of big game winter ranges.

\section{Materials and Methods}

A combination of species and accessions of grasses $(n=16)$ were

\footnotetext{
This report is a contribution of the Utah Division of Widife Resources, Federal Aid Projects W105R, W65R, W82R, and the U.S. For. Serv. Intermountain Research Station. Manuscript accepted 15 Jan. 1994.
}

selected for evaluation. Grass selections are listed in Table 1. Four replicated macroplots were established in a linear rectangular design with $2 \mathrm{~m}$ between macroplots. Each macroplot contained 16 randomly assigned microplots, one for each selection, arranged in a 4 x 4 square. Microplots were separated by $2 \mathrm{~m}$. Within each microplot 16 plants of a selection were established also in a $4 \times 4$ square on $1 \mathrm{~m}$ centers. The only exception was cheatgrass (Bromus tectorum $L$.) which was direct seeded throughout the microplot in fall 1990. All other selections were established as transplants in spring 1990.

The center of each microplot was marked with an identifying color-coded and numbered wooden stake. Plants were watered and weeds were removed during the initial summer (1990) of establishment. Weeds were removed the following spring prior to sampling with deer and again in fall. To investigate differences between deer preferences for irrigated and non-irrigated plants in fall, 2 of the 4 replications were irrigated.

To determine production and nutritive values of selections, before sampling for dietary preferences, 2 plants, ocularly estimated as the mean in size within each microplot, were selected. One-half of each plant was clipped. For cheatgrass, 2 samples were selected to each represent 1/32 of the available biomass on each replication. Thus $1 / 16$ of all plant biomass was removed from each accession. Samples were air-dried, weighed, and subjected to near infrared reflectance spectroscopy (NRI) for nutritional analyses at the Utah State University Soils, Plant and Water Analysis Laboratory.

Sampling for dietary preferences using 5 tame mule deer was completed during spring ( 5 April to 11 May) and fall (12 to 25 September), 1991. During both periods, deer were transported to a holding pen and maintained for 3 days before the first sampling trial. Samples of all grasses were available within the holding pen to facilitate acclimatization to the selections.

Diets were determined by bite counts (Neff 1974) with individual deer used as replications in the diet analyses. Total bite counts for all trials were converted to dry-weight consumption using air-dry weight of 25 simulated bites for each species. Simulated bites were collected mid-way through the sampling periods. During each trial, morning or evening, all deer were released into the research pasture. A pre-determined sampling schedule for deer was followed with a primary and a secondary deer designated for observation. That is, when the primary deer was feeding, it was observed and bites were counted; observations shifted to the secondary deer when the primary deer was not feeding. When neither the primary nor secondary deer were feeding, observations were shifted to a third deer selected at random. Bites were recorded with hand-held tally registers, and number of bites recorded when the observed deer changed grass selection. A rejection was recorded when the observed deer walked through a selection and failed to take a bite, but began foraging on the next selection encoun - 
Table 1. Production, estimated use, and mule deer diet preferences and nutritional parameters for selected grasses in central Utah during spring and fall, 1991.

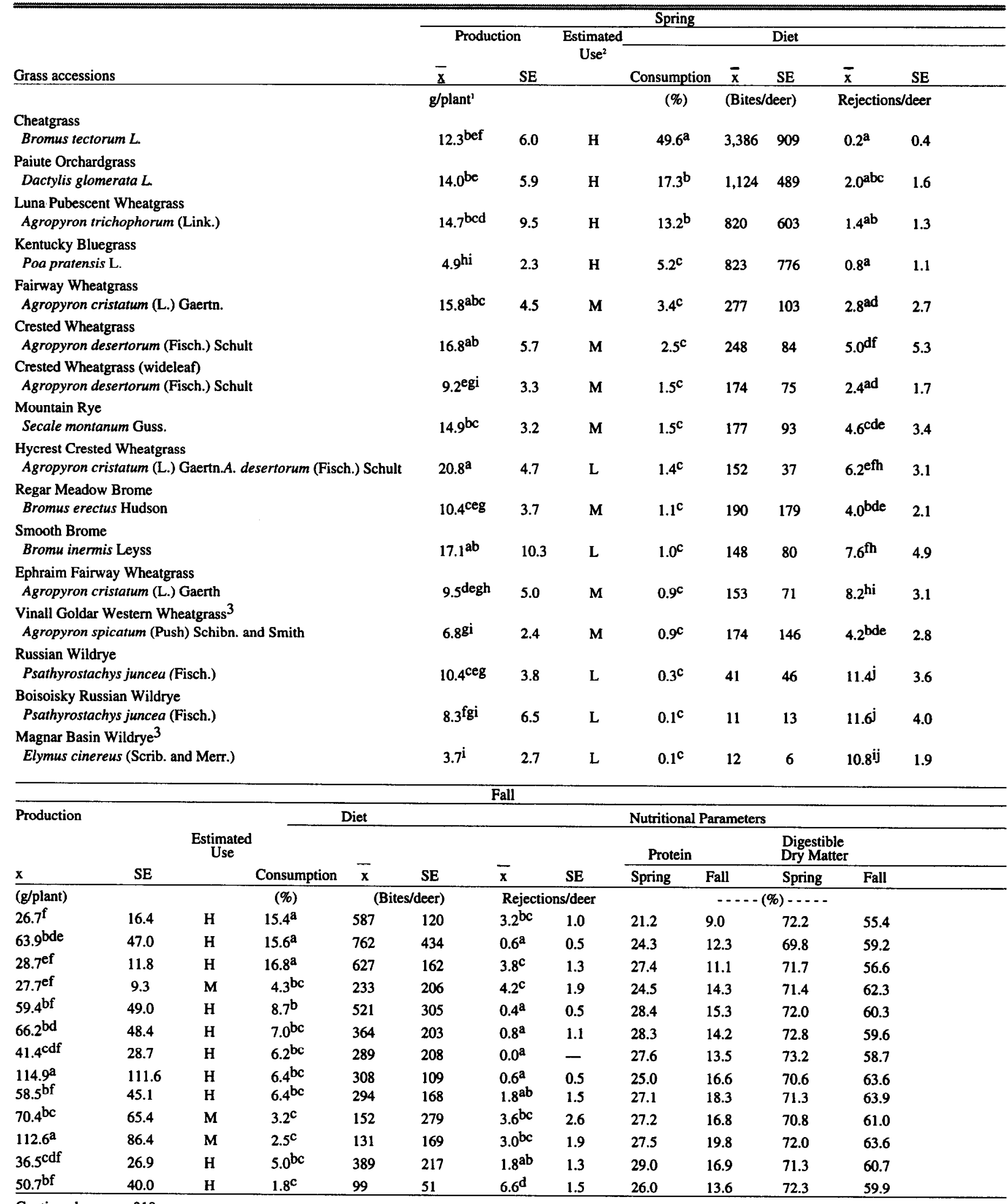

Continued on page 310 


\begin{tabular}{|c|c|c|c|c|c|c|c|c|c|c|c|}
\hline & & & & & & Fall & & & & & \\
\hline Production & & & & Diet & & & & Nutritio & Param & & \\
\hline & & $\begin{array}{c}\text { Estimated } \\
\text { Use }\end{array}$ & & & & & & Prote & & $\begin{array}{l}\text { Digesti } \\
\text { Dry Ma }\end{array}$ & \\
\hline$\underline{x}$ & SE & & Consumption & $\bar{x}$ & SE & $\bar{x}$ & SE & Spring & Fall & Spring & Fall \\
\hline (g/plant) & & & $(\%)$ & & deer) & Reject & s/deer & & $\ldots$ & b) $\ldots .$. & \\
\hline $85.9^{a b}$ & 77.4 & $\mathbf{L}$ & $0.4^{c}$ & 19 & 28 & $7.2^{\mathrm{de}}$ & 2.8 & 30.1 & 20.5 & 73.2 & 63.6 \\
\hline $56.2^{\mathrm{bf}}$ & 58.7 & $\mathbf{L}$ & $0.5^{\mathrm{c}}$ & 34 & 44 & $7.8^{\mathrm{de}}$ & 2.0 & 29.0 & 18.8 & 72.3 & 62.3 \\
\hline $57.8^{b f}$ & 38.1 & $\mathbf{L}$ & $0.1^{c}$ & 8 & 14 & $9.0^{\mathrm{e}}$ & 1.7 & 28.7 & 9.4 & 71.1 & 55.5 \\
\hline
\end{tabular}

'Within columns, means with the same letter are not significantly different $P>0.05$. 2Categories of use by \%: Light 0-5, Moderate 6-25, Heavy $26+$.

Native species.

tered.

Twenty trials were completed in spring, with deer having simultaneous access to all 4 replications. Sixteen trials were completed in fall, with 6 trials on non-irrigated and 10 on irrigated replications. Irrigated and non-irrigated replications were separated by a temporary fence. Trials lasted 2 to 3 hours, and ended when all deer finished foraging.

At the end of spring and fall trials, percent utilization of grass biomass was ocularly estimated for each selection in each replication, by 4 independent observers. Plant use was categorically placed into 3 levels of utilization using the means from the observers: light $0-5 \%$, moderate $6-25 \%$, heavy $26+\%$.

Data sets from spring and fall were analyzed separately. In spring, because of the extremely high variability between trials in total bites and in dietary choice of bites/deer/selection, all 20 trials were combined. In fall, because diets were not different between irrigated and non-irrigated macroplots $(P>0.75)$, all 16 trials were also combined. To determine differences in dietary preferences and rejections among selections, and the variability among deer, 2-way analyses of variance using the repeated measures design (Neter and Wasserman, 1974, Sokal and Rohlf 1981) were used. That is, grass selections were considered treatments $(N=16)$ and deer were replications $(N=5)$. Contrast comparisons were used to separate differences between treatments. Because conclusions from the statistical analyses for both spring and fall diets were the same for bite count and bite counts converted to consumption, only the statistics using the consumptive values are presented.

To determine differences in biomass production between selections for both spring and fall a repeated measures, 2-way analysis of variance was used. Selections were considered treatments $(N=16)$ and clipped plants were replications $(N=8)$. To relate dietary consumption with selection production and nutritional parameters, coefficients of determination $\left(r^{2}\right)$ were obtained.

\section{Results}

Analyses revealed dietary differences among grasses were significant for both spring and fall $(P<0.001)$. A total of 39,557 bites was recorded during spring dietary preference trials and 24,089 in fall.

In spring, cheatgrass was the most preferred selection comprising $49.6 \%$ of the diet (Table 1). Paiute orchardgrass (Dactylis glomerata L.) and Luna pubescent wheatgrass (Agropyron trichophorum Link.) were also preferred. These 3 preferred species comprised $80 \%$ of the diet. The 3 selections of wildrye (Elymus cinereus Scrib. and Merr. and Psathyrostachys juncea Fisch.) received the lowest use and comprised less than $1 \%$ of the diet. Variability among deer was not significant $(P>0.25)$.
Dietary choice of selections was similar in fall. The same 3 preferred selections comprised $48 \%$ of the diet, and the 3 least preferred selections comprised only 1\%. Fairway wheatgrass (Agropyron cristatum [L.] Gaertn.) was also selected in preference to several selections (Table 1). Variability among deer was significant $(P<$ $0.02)$.

Analyses also showed rejection differences among grasses were significant for both spring and fall $(P<0.001)$. A total of 416 and 272 rejections of grass selections were recorded in spring and fall, respectively. The number of rejections were inversely related to selection preferences. In spring and fall combined, the 3 selections of wildrye each contributed about $14 \%$ of all rejections. 'Regar' meadow brome (Bromus erectus Hudson), 'Hycrest' crested wheatgrass (Agropyron cristatum X desertorum [Fisch.] Schult), 'Ephraim' fairway wheatgrass (Agropyron cristatum), smooth brome (Bromus inermis Leyss), and 'Goldar' western wheatgrass (Agropyron spicatum [Push] Scribn. and Smith) each comprised 5-8\% of all rejections. The 8 other selections, including the 3 preferred, each contributed less than $5 \%$.

Differences in dry-weight production among grass selections (Table 1) were significant in both spring and fall $(P<0.001)$. Differences among replications were not significant in spring $(P>$ $0.50)$, but were significant in fall $(P<0.001)$ probably due to differences between irrigated and non-irrigated treatments. In spring, mean production ranged from 3.7 to $17.1 \mathrm{~g} /$ plant and in fall from 26.7 to $114.9 \mathrm{~g} /$ plant. The coefficients of determination relating percent consumption and plant production showed no significant $(P>0.50)$ relationships $\left(r^{2}=0.01,0.16\right)$ for spring or fall.

Utilization estimates mirrored dietary consumption. Use was heavy for the 3 preferred selections, mostly moderate to heavy for the 10 intermediate selections, and light for the 3 wildryes. The highest levels of use occurred on Kentucky bluegrass (Poa pratensis L.) at 47\% in spring, and $64 \%$ for Paiute orchardgrass in fall.

Nutritional parameters among grass selections showed mostly low variability (Table 1) for both spring production and fall regrowth. Except for percent neutral detergent fiber in fall the coefficients of determination $\left(r^{2}\right)$ relating dietary consumption and nutritional parameters were all zero or negative. Most correlations were low $\left(r^{2}<\right.$ 0.30 ). The highest negative correlations between consumption and nutritional parameters were percent protein $\left(r^{2}=-0.59\right)$ and percent total digestible nutrients $\left(r^{2}=-0.50\right)$, both in spring.

\section{Discussion and Conclusions}

Deer showed large differential preferences for the available forages. Dietary preferences were confirmed directly by post-trial estimates of forage utilization, and inversely by observations of forage 
rejections. Results suggest choice of grasses used in revegetation of mule deer winter range may have considerable influence on the degree of grass utilization by deer. Furthermore, in consideration of alternative foraging areas, the choice of seeded selections may influence movement patterns as well as deer numbers. Consequently, revegetation using selections of wildrye might displace deer. Thus, private landowners or highway departments may choose grasses of lower deer preference rankings where perceived competition with livestock for forage or where incidents of deer-vehicle collisions are high. Conversely, managers of wildlife management areas favoring deer should choose grasses preferred by deer.

Even though plant production varied greatly among selections, differences in biomass were not related to deer choices for forages. This was probably due to all forages being adequately abundant, and completion of foraging trials before availability became limiting on any selection.

The nutritional levels of all 16 grass selections in spring and fall were high. Most grasses exceeded $16 \%$ protein (dry matter basis), generally regarded as the level where maximum needs of deer are met (Verme and Ullrey 1972, Urness 1973). Digestible dry matter estimates exceeded $60 \%$ in most grasses, and all other parameters were high in comparison with other deer forages (Dietz et al. 1962, Tueller 1979), and exceeded nutritive requirements where known (Short 1981). Consequently, even though deer in this study preferred grasses with comparatively lower nutritional level was relatively high.

For seeding rangelands with grasses where use by mule deer in spring or fall is desirable, plantings of Paiute orchardgrass, Luna pubescent wheatgrass, and fairway wheatgrass would be preferred. These grasses would complement seeded browse species, native forbs and ubiquitous cheatgrass. For seeding rangelands with grasses where use by mule deer is not desired, Russian or basin wildrye may decrease use.

\section{Literature Cited}

Austin, D. D. and P. J. Urness. 1983. Overwinter forage selection by mule deer on seeded big sagebrush-grass range. J. Wildl. Manage. 47:12031207.

Dietz, D. R., R. D. Udall, and L. E. Yeager. 1962. Chemical composition and digestibility by mule deer of selected forage species, Cache La Poudre range, Colorado. Col. Game and Fish Dept. Tech. Publ. No. 14.

Kufeld, R. C., O. C. Wallmo, and C. Feddema. 1973. Foods of the Rocky Mountain mule deer. USDA For. Serv. Res. Pap. RM-111.

Moen, A. N. 1978. Seasonal changes in heart rates, activity, metabolism and forage intake of white-tailed deer. J. Wild. Manage. 42:715-738.

Neff, D. J. 1974. Forage preferences of trained mule deer on the Beaver Creek watersheds. Ariz. Game and Fish Special Rep. 4.

Neter, J. and W. Wasserman. 1974. Applied Linear Statistical Models. Richard D. Irwin, Inc. Homewood, Ill.

Plummer, A. P., D. R. Christensen, and S. B. Monsen. 1968. Restoring hig game range in Utah. Utah Div. of Fish and Game Publ. No. 68-3.

Short, H. I. 1981. Nutrition and metabolism, p. 99-127. In: O. C. Wallmo, (ed.), Mule and Black-tailed Deer of North America. Univ. of Nebraska Press. Lincoln.

Sokal, R. R. and F. J. Rohlf. 1981. Biometry, 2nd Ed. W. H. Freeman and Company. N.Y.

Tueller, P. T. 1979. Food habits and nutrition of mule deer on Nevada ranges. Final Rep. Nev. Dept. of Fish and Game. Project W-48-5, Study 1, Job 2. Reno.

Urness, P. J. 1973. Chemical analyses and in vitro digestibility of seasonal deer forages, part II, p. 39-52. In: Deer Nutrition in Arizona Chaparral and Desert Habitats. Ariz. Game and Fish Dept. Spec. Rep. 3.

Urness, P. J., D. D. Austin, and L. C. Fierro. 1983. Nutritional value of crested wheatgrass for wintering mule deer. J. Range Manage. 36:225-226.

Verme, L. J., and D. E. Ullrey. 1972. Feeding and nutrition of deer, p. 275 . 291. In: D. C. Church (ed.), The Digestive Physiology and Nutrition of Ruminants. Vol 3. Practical Nutrition. D. C. Church, Corvalis, Ore.

Walmo, O. C., L. H. Carpenter, W. L. Regelin, R. B. Gill, and D. L. Baker. 1977. Evaluation of deer habitat on a nutritional basis. J. Range Manage. 30:122-127.

Willms, M. and A. McLean. 1978. Spring forage selection by tame mule deer on a big sagebrush range, British Columbia. J. Range Manage. 31:192-199. 